\title{
Impact of climate forcing uncertainty and human water use on global and continental water balance components
}

\author{
Hannes Müller Schmied ${ }^{1,2}$, Linda Adam ${ }^{1}$, Stephanie Eisner ${ }^{3}$, Gabriel Fink ${ }^{3}$, Martina Flörke ${ }^{3}$, \\ Hyungjun Kim ${ }^{4}$, Taikan Oki ${ }^{4}$, Felix Theodor Portmann ${ }^{1}$, Robert Reinecke ${ }^{1}$, Claudia Riedel ${ }^{1}$, Qi Song ${ }^{1}$, \\ Jing Zhang ${ }^{1}$, and Petra Döll ${ }^{1}$ \\ ${ }^{1}$ Institute of Physical Geography, Goethe University Frankfurt, Frankfurt, Germany \\ ${ }^{2}$ Senckenberg Biodiversity and Climate Research Centre (BiK-F), Frankfurt, Germany \\ ${ }^{3}$ Center for Environmental Systems Research (CESR), University of Kassel, Kassel, Germany \\ ${ }^{4}$ Institute of Industrial Science, The University of Tokyo, Tokyo, Japan \\ Correspondence to: Hannes Müller Schmied (hannes.mueller.schmied@em.uni-frankfurt.de)
}

Published: 17 October 2016

\begin{abstract}
The assessment of water balance components using global hydrological models is subject to climate forcing uncertainty as well as to an increasing intensity of human water use within the 20th century. The uncertainty of five state-of-the-art climate forcings and the resulting range of cell runoff that is simulated by the global hydrological model WaterGAP is presented. On the global land surface, about $62 \%$ of precipitation evapotranspires, whereas $38 \%$ discharges into oceans and inland sinks. During 1971-2000, evapotranspiration due to human water use amounted to almost $1 \%$ of precipitation, while this anthropogenic water flow increased by a factor of approximately 5 between 1901 and 2010. Deviation of estimated global discharge from the ensemble mean due to climate forcing uncertainty is approximately $4 \%$. Precipitation uncertainty is the most important reason for the uncertainty of discharge and evapotranspiration, followed by shortwave downward radiation. At continental levels, deviations of water balance components due to uncertain climate forcing are higher, with the highest discharge deviations occurring for river discharge in Africa (-6 to $11 \%$ from the ensemble mean). Uncertain climate forcings also affect the estimation of irrigation water use and thus the estimated human impact of river discharge. The uncertainty range of global irrigation water consumption amounts to approximately $50 \%$ of the global sum of water consumption in the other water use sector.
\end{abstract}

\section{Introduction}

The interest in global-scale water resources assessments has increased in the last two decades. There has been an increasing number of publications in this field (Web of Science, topic "global scale" AND "water resources", 1981-1990: 0 entries; 1991-2000: 6 entries; 2001-2010: 64 entries; 2011-2015: 85 entries), and a number of global hydrological models (GHMs) have been developed (Bierkens, 2015). The UN and other international organizations require globalscale information on water resources and their use, e.g. UNESCO's World Water Assessment Programme (www.unesco. org/water/wwap) or the Transboundary Waters Assessment Programme (TWAP, http://www.geftwap.org/twap-project), which can only be provided by modelling approaches due to a lack of observations with global coverage. Such modelbased assessments require meteorological variables as climate forcing input. Currently, a number of state-of-the-art global-scale climate forcings are available that are all based on weather models and differ in terms of methodology including the underlying reanalysis and in terms of observation data used for bias correction. Different climate forcings result in large differences in simulated water fluxes and states as has already been shown by Biemans et al. (2009) for precipitation uncertainty and by Müller Schmied et al. (2014) regarding the uncertainty caused by two climate forcings that differ with respect to other climate variables. Analyses of the impact of different climate forcings are currently the focus of 
Table 1. Summary of climate forcing characteristics used in this study. Abbreviations: precipitation $-P$, temperature $-T$, shortwave downward radiation - SWD, longwave downward radiation - LWD.

\begin{tabular}{|c|c|c|c|c|}
\hline Name & Time span & Basis & Bias correction & Reference \\
\hline GSWP3 & 1901-2010 & $\begin{array}{l}\text { 20th Century Reanalysis } \\
\text { using NCEP atmosphere } \\
\text { land model }\end{array}$ & $\begin{array}{l}\text { GPCC v6 }(P) \text {, and undercatch correc- } \\
\text { tion (Hirabayashi et al., 2008) CRU } \\
\text { TS3.21 (other variables) }\end{array}$ & $\begin{array}{l}\text { http://hydro.iis.u-tokyo. } \\
\text { ac.jp/GSWP3 }\end{array}$ \\
\hline PGFv2 & 1901-2012 & NCEP-NCAR reanalysis & $\begin{array}{l}\text { CRU TS3.21 }(P, T) \text {, no precipitation } \\
\text { undercatch correction, U Maryland, } \\
\text { CRU TS3.21 cloud cover (SWD), U } \\
\text { Maryland (LWD) }\end{array}$ & $\begin{array}{l}\text { Updated version of } \\
\text { Sheffield et al. (2006), } \\
\text { information based on } \\
\text { personal communication } \\
\text { with J. Sheffield (2015) }\end{array}$ \\
\hline WFD & 1901-2001 & ERA-40 reanalysis & $\begin{array}{l}\text { GPCCv4 }(P) \text {, undercatch correction } \\
\text { using Adam and Lettenmaier (2003), } \\
\text { CRU TS } 2.1 \text { cloud cover (SWD), } \\
\text { CRU TS } 2.1 \text { temperature }(T)\end{array}$ & Weedon et al. (2010) \\
\hline WFD_WFDEI & 1901-2010 & $\begin{array}{l}\text { WFD 1901-1978, } \\
\text { WFDEI (based on } \\
\text { ERA-Interim reanalysis) } \\
\text { afterwards }\end{array}$ & $\begin{array}{l}\text { GPCC v5 (v6 for 2010) }(P) \text {, under- } \\
\text { catch correction using Adam and Let- } \\
\text { tenmaier (2003), CRU TS 3.1/3.21 } \\
\text { cloud cover (SWD), CRU TS 3.1/3.21 } \\
\text { temperature }(T)\end{array}$ & Weedon et al. (2014) \\
\hline WFDEI_hom & 1901-2010 & $\begin{array}{l}\text { As WFD_WFDEI, but } \\
\text { WFD homogenized us- } \\
\text { ing a multiplicative ap- } \\
\text { proach for SWD and } \\
\text { LWD and additive ap- } \\
\text { proach for } T\end{array}$ & $\begin{array}{l}\text { Homogenization: Haddeland et al. } \\
\text { (2012), Müller Schmied et al. (2016) }\end{array}$ & \\
\hline
\end{tabular}

model intercomparison studies such as the Inter-Sectoral Impact Model Intercomparison Project (ISIMIP) in its phase 2a, where (among other sectors) several global and regional water models are driven by four state-of-the-art climate forcings and compared to historical observations of, for example, discharge and actual evapotranspiration. In particular, the propagation of climate forcing uncertainty at multiple scales (gridcell level, continental, global) is one topic to be addressed in ISIMIP2a.

Humans increasingly influence the water cycle through water abstractions (Oki and Kanae 2006), in particular for irrigation (e.g. Siebert et al., 2015) but also for other purposes like thermal power plant cooling, manufacturing, livestock production and domestic sectors (Flörke et al., 2013). Quantification of sectoral water abstractions and consumptive water use (also called water consumption, the amount of the abstracted water that evapotranspires during human water use or is incorporated in products), and in particular of the source of water, is highly uncertain due to lack of data (Döll et al., 2016). In some regions, irrigation by groundwater leads to groundwater depletion problems (Döll et al., 2014a; Wada, 2016), and it has been estimated that in groundwater depletion areas, farmers irrigate with only $70 \%$ of the optimal amount of water (Döll et al., 2014a).
Given the large uncertainties, we aim to answer the following research questions by using the Water Global Assessment and Prognosis (WaterGAP) GHM in its version 2.2 (ISIMIP2a):

1. How does climate forcing affect computed runoff at the grid-cell level?

2. How does climate forcing uncertainty and human water use affect long-term average water balance components (including human water use) on global and continental scales?

In Sect. 2 we briefly present the model and climate forcings used in this study. Results are presented and discussed in Sect. 3. The paper ends with a conclusion (Sect. 4), where we answer the research questions, followed by an outlook.

\section{Data and methods}

The global water availability and water use model WaterGAP (Alcamo et al., 2003; Döll et al., 2003; Müller Schmied et al., 2014) was applied using version WaterGAP 2.2 (ISIMIP2a). The main model characteristics of version 2.2 are described in Müller Schmied et al. (2014), and the differences to the ISIMIP2a version are described in Müller Schmied et 

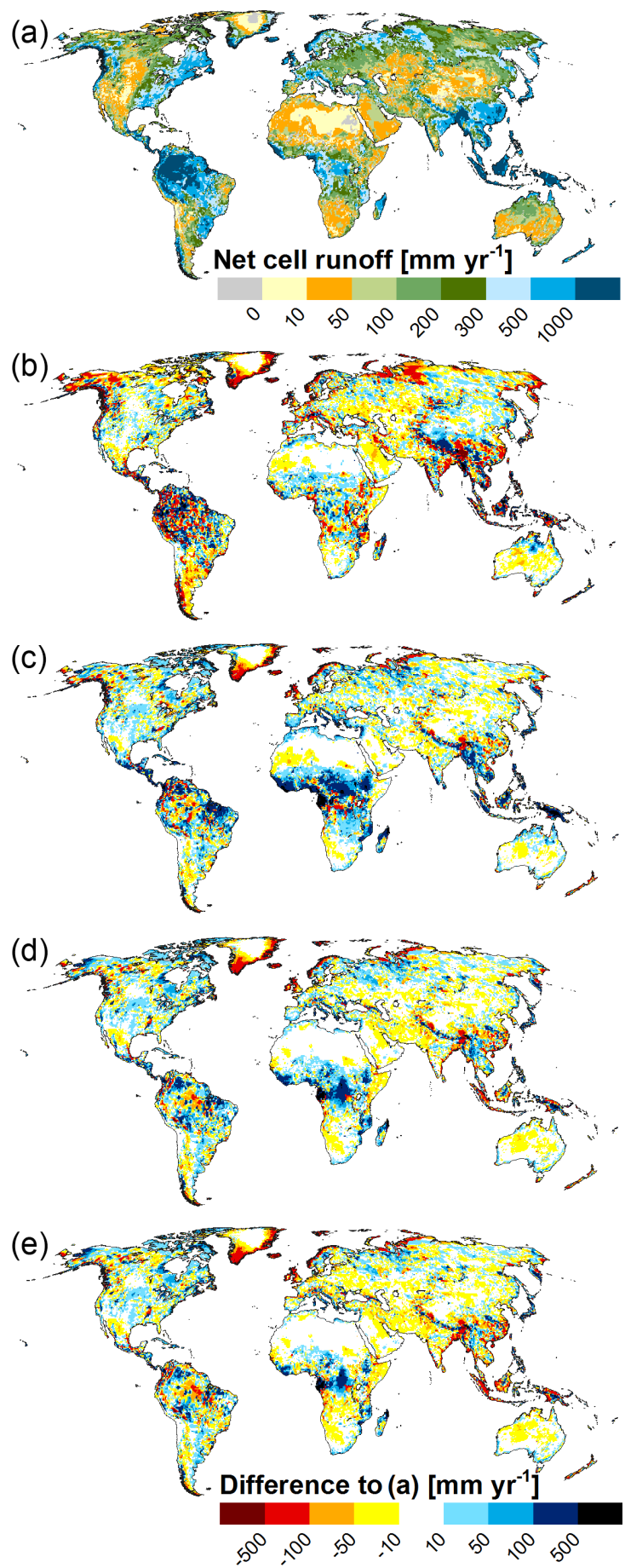

Figure 1. Long-term (1971-2000) average net cell runoff of the model variants, displayed as absolute numbers for GSWP3 (a) and differences to the other forcings, computed as PGFv2 minus GSWP3 (b), WFD minus GSWP3 (c), WFD_WFDEI minus GSWP3 (d) and WFDEI_hom minus GSWP3 (e). Negative values in (a) indicate that water inflow into cell from upstream and by precipitation is larger than outflow due to evaporation from surface wa-

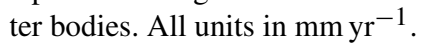

al. (2016). WaterGAP has a spatial resolution of $0.5 \times 0.5^{\circ}$ (i.e. $55 \times 55 \mathrm{~km}$ at the Equator) and consists of five water use models that are linked through the Ground Water Surface Water Use submodule with the WaterGAP global hydrology model (WGHM). Within WGHM, water storage changes in several compartments and freshwater fluxes are modelled at a daily time step. WGHM is calibrated to match long-term average discharge at 1319 observation points (from GRDC database) within $1 \%$ deviation by adjusting one to three parameters (calibration details in Müller Schmied et al., 2014).

Four state-of-the-art climate forcings provided by the Inter-Sectoral Impact Model Intercomparison Project (ISIMIP) in its current phase 2a (https: //www.isimip.org/about/\#simulation-rounds-isimip2a) plus a fifth homogenized forcing were used to force WaterGAP. Table 1 summarizes the main characteristics of all five climate forcing datasets. For a detailed description, the reader is referred to Müller Schmied et al. (2016). The names of the model runs are similar to the names of the climate forcings.

\section{Results and discussion}

\subsection{Global runoff at grid-cell level}

Net cell runoff (computed as outflow minus inflow of each grid cell) differs considerably between the different climate forcing datasets (Fig. 1). This can be attributed to large differences between climate forcings at grid-cell level, in particular with respect to precipitation. Different observational datasets are used to bias-correct $P$ (PGFv2 based on CRU and the others based on different versions of GPCC). This results in large differences (in both directions) at the regional scale for South America and South East Asia. Obviously, the unequal $P$ gauging networks underlying the observational datasets and/or varying regionalization approaches lead to the large differences. In addition, PGFv2 is not corrected for undercatch of solid precipitation (J. Sheffield, personal communication, 2015) while all other datasets are. As undercatch correction (e.g. Adam and Lettenmaier, 2003) leads to the highest $P$ increases in northern (snow-dominated) latitudes, $P$ (and consequently net cell runoff) is lower for PGFv2 (red areas in the northern latitudes in Fig. 1b).

The main reason for the large discrepancies between GSWP3 and WFD in equatorial regions (Fig. 1c) is attributable to systematically smaller SWD (Fig. A3c) in energy-limited areas for the WFD dataset. This effect is lessened in the combined WFD_WFDEI dataset (Fig. 1d) and even more in the homogenized forcing WFDEI_hom (Fig. 1e), as WFDEI shows systematically higher SWD than WFD. The higher SWD in parts of Asia, western Africa and Australia (Fig. A3d, e) does not influence net cell runoff significantly because these regions are water-limited: evaporation and runoff are mainly controlled by precipitation and not by available energy. In many regions where SWD is in- 


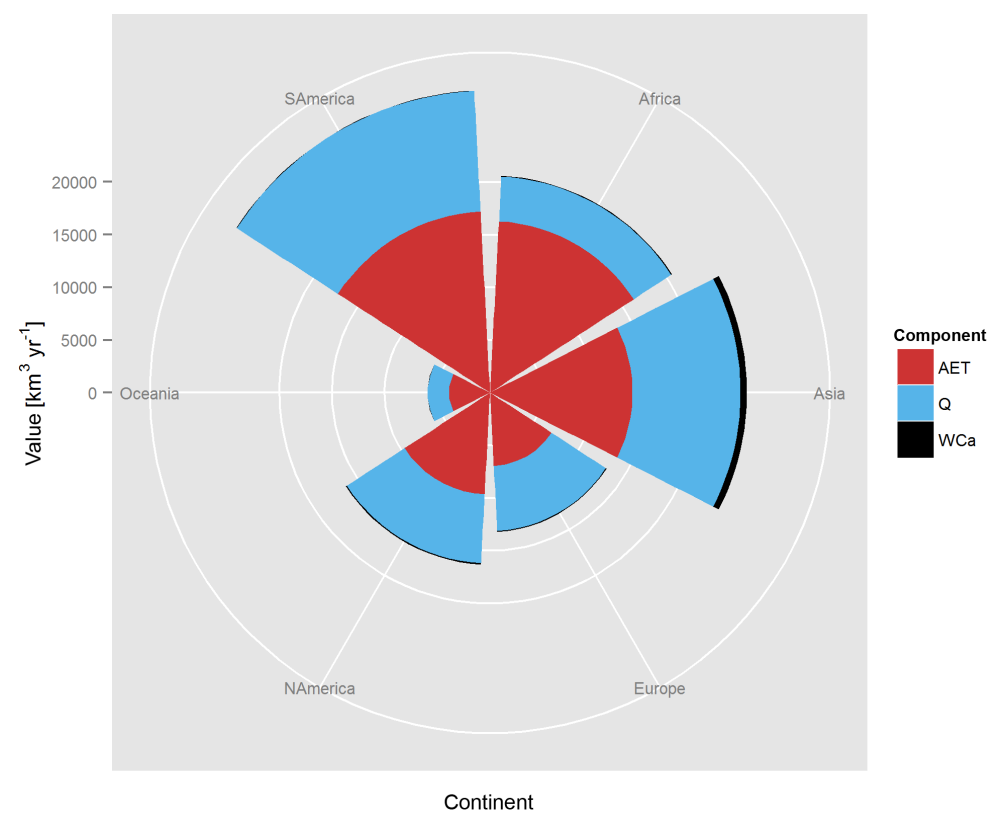

Figure 2. Continental water balance components 1971-2000 $\left(\mathrm{km}^{3} \mathrm{yr}^{-1}\right)$; ensemble mean of the five climate forcings. Abbreviations: actual evapotranspiration (AET), discharge into oceans and inland sinks $(Q)$, actual water consumption (WCa).

Table 2. Global water balance components for land area (except Antarctica and Greenland) in \% of precipitation (row 1) for the five model variants and 1971-2000. Cells representing inland sinks were excluded but discharge into inland sinks was included.

\begin{tabular}{llrrrrr}
\hline No. & Component & GSWP3 & PGFv2 & WFD & WFDEI_hom & WFD_WFDEI \\
\hline 1 & Precipitation $P\left(\mathrm{~km}^{3} \mathrm{yr}^{-1}\right)$ & 109631 & 103525 & 110690 & 111050 & 111050 \\
2 & Actual evapotranspiration AET & 62.0 & 61.3 & 61.1 & 63.0 & 62.0 \\
3 & Discharge into oceans and inland sinks $Q^{\mathrm{b}}$ & 37.1 & 37.8 & 38.1 & 36.2 & 37.2 \\
4 & Water consumption (actual) WCa & 0.9 & 0.9 & 0.8 & 0.9 & 0.8 \\
5 & Change of total water storage d $S / \mathrm{d} t^{\mathrm{c}}$ & -0.01 & -0.03 & -0.02 & -0.02 & -0.07 \\
\hline
\end{tabular}

a AET does not include evapotranspiration caused by human water use, i.e. actual water consumption WCa. ${ }^{\mathrm{b}}$ Taking into account anthropogenic water use.

c Total water storage (TWS) of 31 December 2000 minus TWS of 31 December 1970, divided by the number of 30 years.

creased, LWD is decreased (and vice versa), which reduces the effect on net radiation. $T$ effects model results via the equation for potential evapotranspiration (Priestley and Taylor, 1972), via snow dynamics as well as the leaf area index model that affects canopy evaporation (details in Müller Schmied et al., 2014). As $T$ differs only little between the forcing datasets (Fig. A2), effects of $T$ differences on simulated net cell runoff are expected to be relatively small.

\subsection{Continental water balance components}

Figure 2 displays the continental-scale partitioning of precipitation into actual evapotranspiration AET, river discharge $Q$, and human water consumption WCa. South America and Africa have nearly the same absolute amount of AET, but values for $Q$ differ strongly. As a consequence of extensive irrigated agriculture especially in India and China (Siebert et al., 2015), the highest water consumption occurs in Asia, where
$2.5 \%$ of precipitation is evapotranspired, mainly due to irrigation. For the other continents, water consumption plays - relative to the other water balance components - only a marginal role. The lowest runoff coefficient $(Q / P)$ is found in Africa (0.21), whereas runoff coefficients vary between 0.34 (Oceania) and 0.47 (Europe) for the other continents. Hence, differences in $P$ result in higher relative uncertainties of estimated water resources for Africa. The deviation from the mean continental value for $Q$ among the climate forcings is between -5.9 (calculated as $\min Q /$ mean $Q$ ) and $10.9 \%$ (max $Q /$ mean $Q$ ) for Africa, whereas for all other continents deviations are lower $(-5.4$ and -2.2 as minimum $Q$, $2.5-5.0 \%$ as maximum $Q$ ).

\subsection{Global water balance components}

Compared to the continental-scale deviation of water balance components, the impact of climate forcing uncertainty 


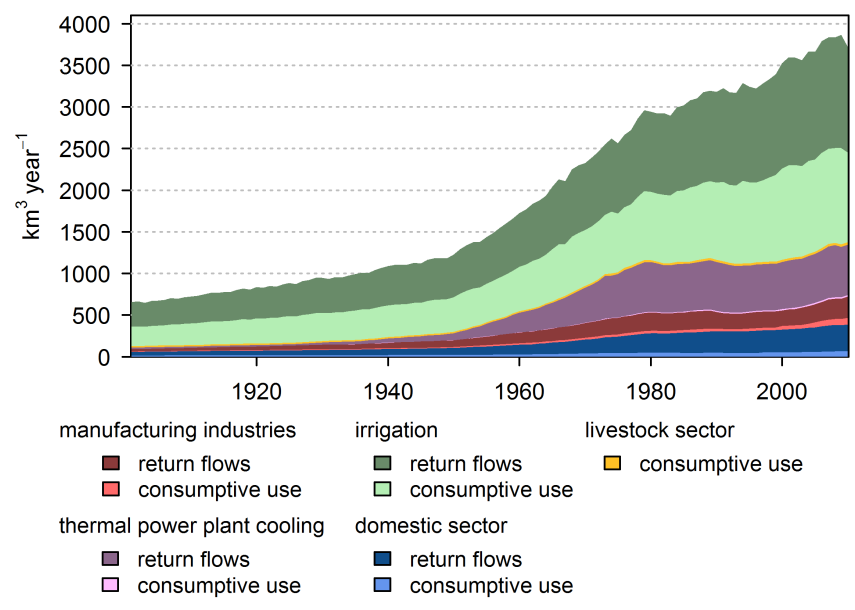

Figure 3. Development of water abstractions (sum of return flows and consumptive use) and water consumption (the amount of water that is evapotranspired or incorporated in products, light colours) of the five water use sectors considered in WaterGAP for 1901-2010. Values for irrigation (modelled with $70 \%$ of demand in grid cells with groundwater depletion) are averaged across the five climate forcings; other sectors are modelled independently of climate forcing and taken from Flörke et al. (2013).

is levelling out at the global scale to a certain degree (Table 2). Global runoff coefficients vary between 0.362 and 0.381 , and deviation of global $Q$ from the ensemble mean is -3.8 to $3.7 \%$. Actual evapotranspiration is estimated to range between 61.1 and $63.0 \%$ of global $P$ (Table 2). The lowest value for AET (and highest value for $Q$ ) is computed when using WFD climate forcing. Here, average global SWD is $15 \mathrm{~W} \mathrm{~m}^{-2}$ lower compared to the other forcings (see also Müller Schmied et al., 2016, their Fig. 1). In absolute numbers, differences in AET and $Q$ resulting from the five climate forcings are considerable. For example, global discharge values range from 39200 to $42200 \mathrm{~km}^{3} \mathrm{yr}^{-1}$ : the uncertainty range is equal to thrice the total water consumption ( 930 $\left.\mathrm{km}^{3} \mathrm{yr}^{-1}\right)$.

On the global scale, sectoral water uses have strongly increased since 1901 (Fig. 3). Whereas overall water abstractions (consumptive use) are about 650 (260) $\mathrm{km}^{3} \mathrm{yr}^{-1}$ in the year 1901, values are about 5 times higher with 3700 (1250) $\mathrm{km}^{3} \mathrm{yr}^{-1}$ in 2010. In contrast to Müller Schmied et al. (2016, their Fig. 1), where water consumption of each climate forcing is presented using different time step aggregations, Fig. 3 shows the proportion of potential (if water were available without limitation) consumptive water use components (light colours) and the amount of return flows (dark colours). The most important water use sector regarding both abstraction and consumption is the irrigation sector. The sum of potential water consumption of all water use sectors (except irrigation) throughout the period 1971-2000 is $112 \mathrm{~km}^{3} \mathrm{yr}^{-1}$, whereas the sums of potential irrigation water consumption vary between 834 and $894 \mathrm{~km}^{3} \mathrm{yr}^{-1}$ depend- ing on the climate forcings. Together with the other potential water uses (manufacturing, cooling of thermal power plants, domestic and livestock sector), the demand of consumptive water uses ranges from 946 to $1006 \mathrm{~km}^{3} \mathrm{yr}^{-1}$. Due to limited water availability to satisfy the demand, actual water consumption (WCa) ranges between 915 (WFD) and 960 (PGFv2) $\mathrm{km}^{3} \mathrm{yr}^{-1}$ (all numbers 1971-2000). Hence, water availability reduces the impact of climate forcing uncertainty when modelling water use demand. The uncertainty range of estimated global irrigation water consumption due to the climate forcing is therefore about $50 \%$ of the sum of all the other water use sectors.

\section{Conclusions}

Within this study, the WaterGAP 2.2 (ISIMIP2a) model was used to assess water balance components on grid-cell, continental and global scale as well as the development of human water use on the global scale. The research questions can be answered as follows:

1. How does climate forcing affect computed runoff at the grid-cell level?

On the grid-cell level, the effect of climate forcing uncertainty on computed runoff is very large. In particular, usage of different observation-based products to bias-correct reanalysis data affects the spatial distribution of runoff. Furthermore, undercatch correction (or the lack thereof) of $P$ leads to differences in model estimates. Whereas $T$ uncertainty does not lead to clearly visible spatial differences in computed runoff, SWD uncertainty was found to have a large impact in energy-limited regions like tropical Africa. For water-limited areas, this is not the case.

2. How does climate forcing uncertainty and human water use affect long-term average water balance components on global and continental scales?

Climate forcing uncertainty is high (Figs. A1-A4), and most important are differences in $P$ and SWD. At the continental scale, these uncertainties lead to large differences in calculated water balance components, in particular in regions with high $P$ uncertainty and low runoff coefficient (e.g. Africa). Global-scale values vary less in relative terms as deviations even out with spatial aggregation. The uncertainty range of estimated global irrigation water consumption due to uncertain climate forcing is around $50 \%$ of the water consumption in the other water use sectors.

Multi-model hydrological assessments as done by the ISIMIP initiative for both historical periods (e.g. Haddeland et al., 2011) and future scenarios (e.g. Schewe et al., 2014) will help to relate the uncertainties of water balance components at different scales of aggregation that are caused by different climate forcings to uncertainties due to the hydrological models themselves. To constrain both types of uncertainty, model calibration not only of mean annual river 
discharge (as done for the WaterGAP model) but also of remote-sensing-based data like total water storage variations from GRACE (Eicker et al., 2014; Döll et al., 2014b, 2016) is promising, but collection and sharing of in situ data remains crucial (Fekete et al., 2015).

\section{Data availability}

The WaterGAP output will become freely available to the public within the framework of the ISIMIP project phase 2a, but it is not yet clarified where the data will be hosted (please check https://www.isimip.org/outputdata/ for updates). The homogenized climate forcing WFDEI_hom is not included within the ISI-MIP project. All model outputs used in this study are available on request from the corresponding author. 


\section{Appendix A}
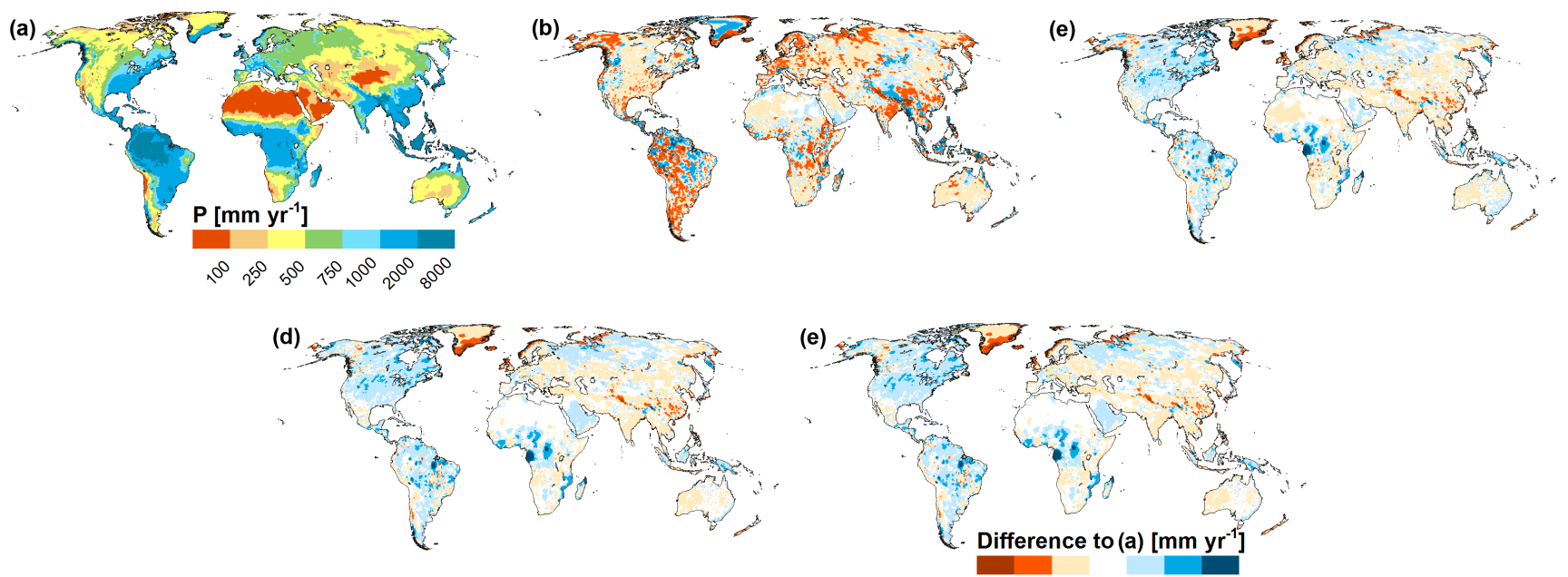

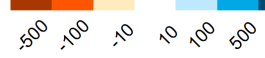

Figure A1. Long-term (1971-2000) average precipitation of the model variants, displayed as absolute number for GSWP3 (a) and differences to the other forcings, computed as PGFv2 minus GSWP3 (b), WFD minus GSWP3 (c), WFD_WFDEI minus GSWP3 (d), and WFDEI_hom minus GSWP3 (e). All units in $\mathrm{mm} \mathrm{yr}^{-1}$.
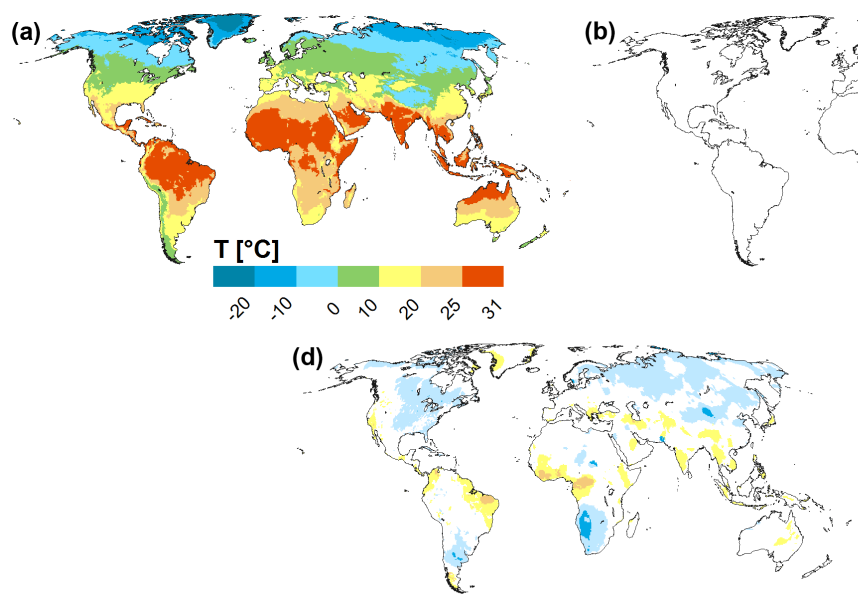

(b)

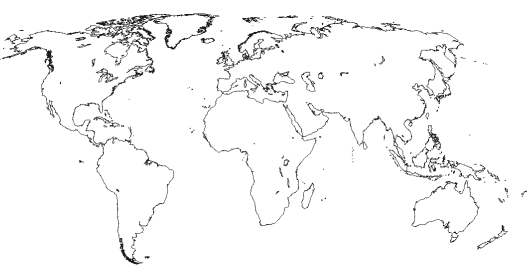

(e)

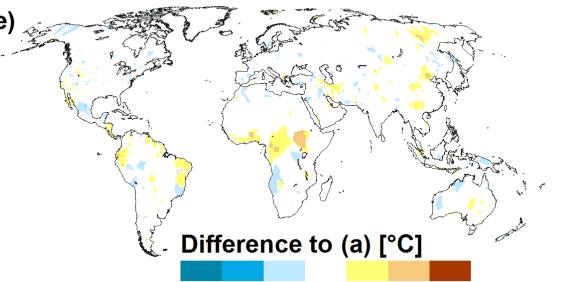

(c)

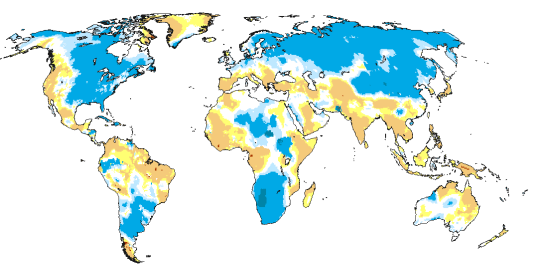

$\therefore 0.0 \%$ a

Figure A2. Long-term (1971-2000) average temperature of the model variants, displayed as absolute number for GSWP3 (a) and differences to the other forcings, computed as PGFv2 minus GSWP3 (b), WFD minus GSWP3 (c), WFD_WFDEI minus GSWP3 (d), and WFDEI_hom minus GSWP3 (e). All units in ${ }^{\circ} \mathrm{C}$. 
(a)

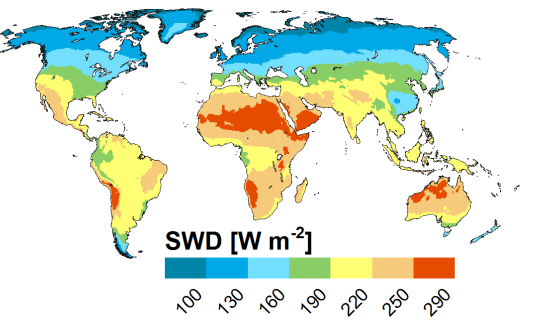

(b)

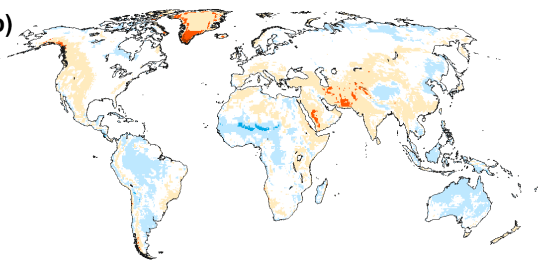

(c)

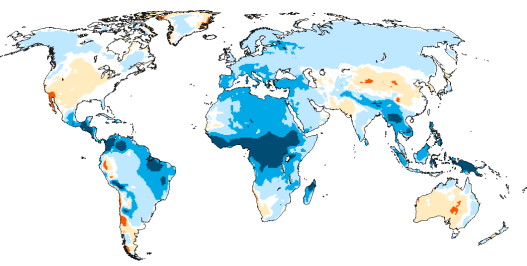

(d)

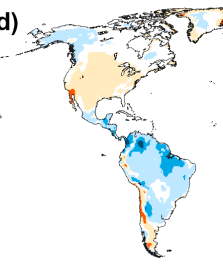

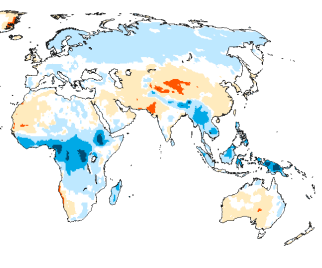

(e)

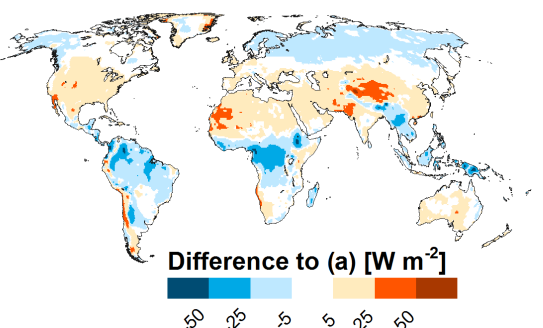

Figure A3. Long-term (1971-2000) average shortwave downward radiation of the model variants, displayed as absolute number for GSWP3 (a) and differences to the other forcings, computed as PGFv2 minus GSWP3 (b), WFD minus GSWP3 (c), WFD_WFDEI minus GSWP3 (d), and WFDEI_hom minus GSWP3 (e). All units in $\mathrm{W} \mathrm{m}^{-2}$.

(a)

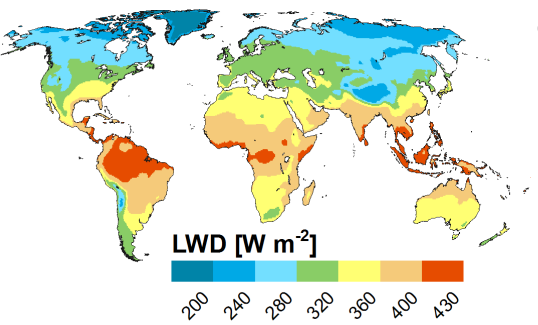

(b)

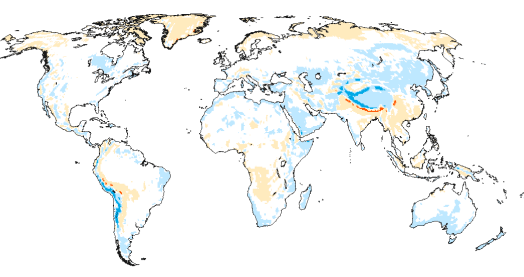

(c)

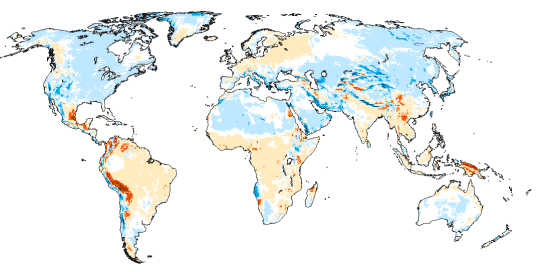

(d)

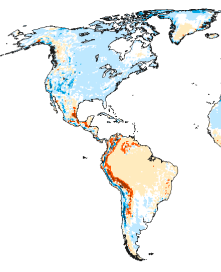

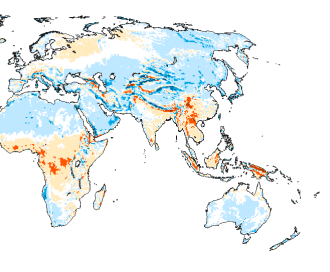

(e)

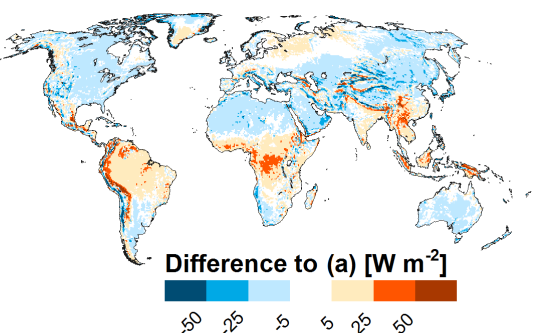

Figure A4. Long-term (1971-2000) average longwave downward radiation of the model variants, displayed as absolute number for GSWP3 (a) and differences to the other forcings, computed as PGFv2 minus GSWP3 (b), WFD minus GSWP3 (c), WFD_WFDEI minus GSWP3 (d), and WFDEI_hom minus GSWP3 (e). All units in W $\mathrm{m}^{-2}$. 
Acknowledgements. The authors thank the Global Runoff Data Centre (GRDC, http://grdc.bafg.de), 56068 Koblenz, Germany, for providing the discharge data used in this study for calibrating the model. We are also grateful to the ISI-MIP coordination team as well as the leaders of the water sector (Simon Gosling and Rutger Dankers) for providing the climate forcings and the support. Furthermore, we thank Wolfgang Grabs for organizing the international conference "Water Resources Assessment \& Seasonal Prediction" (13-16 October in Koblenz, Germany), where some content of this paper was presented.

\section{References}

Adam, J. C. and Lettenmaier, D. P.: Adjustment of global gridded precipitation for systematic bias, J. Geophys. Res., 108, 4257, doi:10.1029/2002JD002499, 2003.

Alcamo, J., Döll, P., Henrichs, T., Kaspar, F., Lehner, B., Rösch, T., and Siebert, S.: Development and testing of the WaterGAP 2 global model of water use and availability, Hydrol. Sci. J., 48, 317-337, doi:10.1623/hysj.48.3.317.45290, 2003.

Biemans, H., Hutjes, R. W. A., Kabat, P., Strengers, B. J., Gerten, D., and Rost, S.: Effects of precipitation uncertainty on discharge calculations for main river basins, J. Hydrometeorol., 10, 10111025, doi:10.1175/2008JHM1067.1, 2009.

Bierkens, M. F. P.: Global hydrology 2015: state, trends and directions, Water Resour. Res., 51, 4923-4947, doi:10.1002/2015WR017173, 2015.

Döll, P., Kaspar, F., and Lehner, B.: A global hydrological model for deriving water availability indicators: model tuning and validation, J. Hydrol., 270, 105-134, doi:10.1016/S00221694(02)00283-4, 2003.

Döll, P., Müller Schmied, H., Schuh, C., Portmann, F. T., and Eicker, A.: Global-scale assessment of groundwater depletion and related groundwater abstractions: Combining hydrological modeling with information from well observations and GRACE satellites, Water Resour. Res., 50, 5698-5720, 2014a.

Döll, P., Fritsche, M., Eicker, A., and Müller Schmied, H.: Seasonal water storage variations as impacted by water abstractions: Comparing the output of a global hydrological model with GRACE and GPS Observations, Surv. Geophys, 35, 1311-1331, doi:10.1007/s10712-014-9282-2, 2014b.

Döll, P., Douville, H., Güntner, A., Müller Schmied, H., and Wada, Y.: Modelling freshwater resources at the global scale: Challenges and prospects, Surv. Geophys., 37, 195-221, doi:10.1007/s10712-015-9347-x, 2016.

Eicker, A., Schumacher, M., Kusche, J., Döll, P., and Müller Schmied, H.: Calibration/data assimilation approach for integrating GRACE data into the WaterGAP Global Hydrology Model (WGHM) using an Ensemble Kalman Filter: First results, Surv. Geophys., 35, 1285-1309, doi:10.1007/s10712-014-93098, 2014.

Fekete, B. M., Robarts, R. D., Kumagai, M., Nachtnebel, H.-P., Odada, E., and Zhulidov, A. V.: Time for in situ renaissance, Science, 349, 685-686, doi:10.1126/science.aac7358, 2015.

Flörke, M., Kynast, E., Bärlund, I., Eisner, S., Wimmer, F., and Alcamo, J.: Domestic and industrial water uses of the past 60 years as a mirror of socio-economic development: A global simulation study, Global Environ. Chang., 23, 144-156, doi:10.1016/j.gloenvcha.2012.10.018, 2013.
Haddeland, I., Clark, D. B., Franssen, W., Ludwig, F., Voß, F., Arnell, N. W., Bertrand, N., Best, M., Folwell, S., Gerten, D., Gomes, S., Gosling, S. N., Hagemann, S., Hanasaki, N., Harding, R., Heinke, J., Kabat, P., Koirala, S., Oki, T., Polcher, J., Stacke, T., Viterbo, P., Weedon, G. P., and Yeh., P.: Multi-model estimate of the global terrestrial water balance: Setup and first results, J. Hydrometeorol., 12, 869-884, doi:10.1175/2011JHM1324.1, 2011.

Haddeland, I., Heinke, J., Voß, F., Eisner, S., Chen, C., Hagemann, S., and Ludwig, F.: Effects of climate model radiation, humidity and wind estimates on hydrological simulations, Hydrol. Earth Syst. Sci., 16, 305-318, doi:10.5194/hess-16-305-2012, 2012.

Hirabayashi, Y., Kanae, S., Motoya, K., Masuda, K., and Döll, P.: A 59-year (1948-2006) global meteorological forcing data set for land surface models. Part II: Global snowfall estimation, Hydrol. Res. Lett., 2, 65-69, doi:10.3178/hrl.2.65, 2008.

Müller Schmied, H., Eisner, S., Franz, D., Wattenbach, M., Portmann, F. T., Flörke, M., and Döll, P.: Sensitivity of simulated global-scale freshwater fluxes and storages to input data, hydrological model structure, human water use and calibration, Hydrol. Earth Syst. Sci., 18, 3511-3538, doi:10.5194/hess-183511-2014, 2014.

Müller Schmied, H., Adam, L., Eisner, S., Fink, G., Flörke, M., Kim, H., Oki, T., Portmann, F. T., Reinecke, R., Riedel, C., Song, Q., Zhang, J., and Döll, P.: Variations of global and continental water balance components as impacted by climate forcing uncertainty and human water use, Hydrol. Earth Syst. Sci., 20, 28772898, doi:10.5194/hess-20-2877-2016, 2016.

Oki, T. and Kanae, S.: Global hydrological cycles and world water resources, Science, 313, 1068-1072, doi:10.1126/science.1128845, 2006.

Priestley, C. H. B. and Taylor, R. J.: Assessment of surface heat flux and evaporation using large-scale parameters, Mon. Weather Rev., 100, 81-92, doi:10.1175/15200493(1972)100<0081:OTAOSH>2.3.CO;2, 1972.

Schewe, J., Heinke, J., Gerten, D., Haddeland, I., Arnell, N. W., Clark, D. B., Dankers, R., Eisner, S., Fekete, B. M., ColónGonzález, F. J., Gosling, S. N., Kim, H., Liu, X., Masaki, Y., Portmann, F. T., Satoh, Y., Stacke, T., Tang, Q., Wada, Y., Wisser, D., Albrecht, T., Frieler, K., Piontek, F., Warszawski, L., and Kabat, P.: Multimodel assessment of water scarcity under climate change, P. Natl. Acad. Sci. USA, 111, 3245-3250, doi:10.1073/pnas.1222460110, 2014.

Sheffield, J., Goteti, G., and Wood, E. F.: Development of a 50-year high-resolution global dataset of meteorological forcings for land surface modeling, J. Climate, 19, 3088-3111, doi:10.1175/JCLI3790.1, 2006.

Siebert, S., Kummu, M., Porkka, M., Döll, P., Ramankutty, N., and Scanlon, B. R.: A global data set of the extent of irrigated land from 1900 to 2005, Hydrol. Earth Syst. Sci., 19, 1521-1545, doi:10.5194/hess-19-1521-2015, 2015.

Wada, Y.: Modeling groundwater depletion at regional and global scales: Present state and future prospects, Surv. Geophys., 37, 419-451, doi:10.1007/s10712-015-9347-x, 2016.

Weedon, G. P., Gomes, S., Viterbo, P., Österle, H., Adam, J. C., Bellouin, N., Boucher, O., and Best, M.: The WATCH Forcing Data: a meteorological forcing dataset for land surface- and hydrological models, Watch Techn. Rep., 22, 41 pp., available at: http: //www.eu-watch.org/media/default.aspx/emma/org/10376311/ 
WATCH+Technical+Report+Number+22+The+WATCH+ forcing+data+1958-2001+A+meteorological+forcing+dataset+ for+land+surface-+and+hydrological-models.pdf (last access 29 July 2016), 2010.
Weedon, G. P., Balsamo, G., Bellouin, N., Gomes, S., Best, M. J., and Viterbo, P.: The WFDEI meteorological forcing data set: WATCH Forcing Data methodology applied to ERAInterim reanalysis data, Water Resour. Res., 50, 7505-7514, doi:10.1002/2014WR015638, 2014. 